\title{
KORELASI KADAR ASAM URAT DALAM DARAH DAN KRISTAL ASAM URAT DALAM URINE
}

\author{
Tadjuddin Naid, Ita Ayuningsih Mas'ud, Kus Haryono
}

Fakultas Farmasi Universitas Hasanuddin Makassar

Email : tadjuddinnaid@yahoo.co.id

\begin{abstract}
The study had been done about the correlation test betweenblood uric acid level, and urine uric acid cristal. The objective of this study was to find the correlation betweenblood uric acid level, and urine uric acid cristal. This studywas an observational study with cross sectional approach using serum and urine samples were taken from patients who have met the criteria of the study sample. The samples number are36 that all of them analyzed with test blood uric acid, and urine uric acid cristal.The data of result was processed and analyzed with statistic test of correlation test. The results of study showed that there are correlation between blood uric acid level and urine urine uric acid, that the more uric acid cristal exrated viaurine will make to reduce blood uric acid level.
\end{abstract}

Keywords: blood, uric acid, urine.

\section{PENDAHULUAN}

Peningkatan usia harapan hidup dan status gizi masyarakat pada beberapa dekade terakhir ini telah menyebabkan perubahan pola penyakit dari pola penyakit infeksi menjadi penyaki degeneratif (1). Perubahan pola penyakit tersebut berhubungan dengan perubahan pola makan dari pola makan tradisional yang mengandung banyak karbohidrat dan serat sayuran ke pola makan dengan komposisi mengandung banyak protein, lemak, gula, garam dan sedikit serat. Hiperurisemia merupakan salah satu tanda dari penyakit tidak menular yang disebabkan oleh perubahan pola makan tersebut (2). Hiperurisemia atau lebih dikenal dengan meningkatnya kadar asam urat di dalam darah, adalah suatu penyakit gangguan kinetik asam urat (2). Asam urat merupakan hasil akhir dari metabolisme purin. Peningkatan kadar asam urat dalam darah (hiperurisemia) yang berlebihan disebabkan oleh dua kemungkinan utama: kelebihan produksi asam urat atau terhambatnya pembuangan asam urat oleh tubuh (3).

Asam urat terbentuk jika kita mengkonsumsi makanan yang banyak 
mengandung purin. Jika pola makan kita tidak di ubah maka kadar asam urat dalam darah yang berlebihan akan menimbulkan penumpukan kristal asam urat (4). Bila kristal urat tertimbun pada jaringan di luar sendi maka akan membentuk tofi atau topus yaitu benjolan bening di bawah kulit yang berisi kristal urat. Kristal urat ini juga dapat menyebabkan timbulnya batu asam urat (batu ginjal) (5).

Pada pemeriksaan laboratorium didapatkan kadar asam urat yang tinggi dalam darah $>7 \mathrm{mg} / \mathrm{dl}$. Kadar asam urat normal dalam serum pada pria $7 \mathrm{mg} / \mathrm{dl}$ dan pada wanita $6 \mathrm{mg} / \mathrm{dl}$ (6). Pemeriksaan kadar asam urat ini akan lebih tepat lagi bila dilakukan dengan cara enzimatik. Kadar asam urat pada orang dewasa cenderung meningkat dengan bertambahnya usia, berat badan, tekanan darah, konsumsi alkohol dan gangguan fungsi ginjal (7).

\section{METODE PENELITIAN}

\section{Jenis dan tempat penelitian}

Jenis penelitian ini adalah studi cross sectional yaitu untuk mengetahui hubunganKadar Asam Urat Dalam Darah dan Kristal Asam Urat Dalam Urine. Penelitian dilakukan di Balai Besar Laboratorium Kesehatan.

\section{Populasi dan sampel penelitian}

Populasi dalam penelitian ini adalah seluruh pasien rawat jalan usia dewasa laki-laki dan perempuan yang memeriksakan ke Balai Besar Laboratorium Kesehatan Makassar dengan pemeriksaan asam urat. Sampel darah dan urine diambil sebanyak 36 sampel pemeriksaan asam urat dari jumlah populasi sampel. Teknik pengambilan sampel adalah dengan menggunakan teknik accidental sampling. Kriteria inklusi sampel penelitian adalah pasien rawat jalan dengan pemeriksaan asam urat, setuju untuk diikutkan dalam penelitian, dan menandatangani informed concent. Kriteria eksklusi pada penelitian ini adalah sampel mengalami hemolisis dan ikterik.

\section{Alat dan Bahan}

Alat-alat yang digunakan adalah spoit, tourniquet, tabung sentrifus, tabung vacum, raktabung, kapas, pipet pasteur, sentrifus, kaca objek, fotometer, dan mikroskop.

Bahan yang digunakan adalah serum, sedimen urine, alkohol $70 \%$, dan reagen (R1 Phosphate buffer $\mathrm{pH}$ 7,4, DHBSA, Uricase, POD, 4aminoantipyrine).

\section{Prosedur Kerja}

Pasien yang berpartisipasi menjadi subjek dalam penelitian ini sebelum diambil darah vena dilakukan pengisian Impormed Consent sebagai Persetujuan Setelah Penjelasan (PSP) 
sesuai dengan lampiran dalam Pengajuan Uji Klinik Komisi Etik Fakultas Kedokteran Universitas Hasanuddin.

\section{Analisis Data}

Pengolahan data penelitian menggunakan SPSS dengan uji statistik korelasi.

\section{HASIL PENELITIAN}

Telah dilakukan penelitian tentang pemeriksaan kadar asam urat Asam Urat Dalam Darah dan Kristal Asam Urat Dalam Urine

dalam darah dan kristal asam urat dalam urine di Balai Besar Laboratorium Kesehatan Makassar sebanyak 36 sampel. Sebesar $36,1 \%$ sampel berada pada rentang usia 2337 tahun. Sebagian sampel lainnya berada pada retang usia 53-57 tahun (27,8\%), 68-82 tahun (22,2\%), dan 3852 tahun (13,9\%) (Tabel 1).

Tabel 1. Distribusi sampel berdasarkan Umur pada Pemeriksaan Korelasi Kadar

\begin{tabular}{|c|c|c|c|}
\hline No. & Umur (Tahun) & Jumlah & Persen (\%) \\
\hline 1 & $23-37$ & 13 & 36,1 \\
\hline 2 & $38-52$ & 5 & 13,9 \\
\hline 3 & $53-57$ & 10 & 27,8 \\
\hline 4 & $68-82$ & 8 & 22,2 \\
\hline \multicolumn{2}{|r|}{ Total } & 36 & 100 \\
\hline
\end{tabular}

Tabel 2. Distribusi Sampel berdasarkan Hasil Pemeriksaan Korelasi Kadar Asam Urat Dalam Darah dan Kristal Asam Urat Dalam Urine

\begin{tabular}{cccccccc}
\hline \multirow{2}{*}{ No. } & \multirow{2}{*}{ Hasil Pemeriksaan } & \multicolumn{3}{c}{ Jumlah } & \multicolumn{2}{c}{ Total } \\
\cline { 3 - 8 } & & \multicolumn{2}{c}{ Normal } & \multicolumn{2}{c}{ Tidak Normal } & N & $\%$ \\
\hline 1 & Asam Urat & 12 & 33,3 & 24 & 66,7 & 36 & 100 \\
2 & Kristal Asam Urat & 29 & 80,6 & 7 & 19,4 & 36 & 100 \\
\hline
\end{tabular}

Tabel 3. Hasil uji Korelasi

\begin{tabular}{|c|c|c|}
\hline & Kristal Asam Urat & Asam Urat \\
\hline Kristal Asam urat Pearson Correlation & 1 & 0,725 \\
\hline Sig. (2-tailed) & & .000 \\
\hline $\mathrm{N}$ & 36 & 36 \\
\hline Asam Urat Pearson Correlation & $0,725^{* *}$ & 1 \\
\hline Sig. (2-tailed) & .000 & \\
\hline $\mathrm{N}$ & 36 & 36 \\
\hline
\end{tabular}

Korelasi signifikan pada level 0,01 (2-tailed) 


\begin{abstract}
Sebagian besar sampel mengalami ketidaknormalan pemeriksaan asam urat, yaitu sebesar $66,7 \%$. Sementara pada pemeriksaan Kristal asam urat, sebagian besar responden memiliki hasil pemeriksaan yang normal, yaitu $80,6 \%$ (Tabel 2). Berdasarkan hasil uji korelasi, diketahui bahwa terdapat hubungan yang kuat antara kadar asam urat dalam darah dengan kristal asam urat dalam urine, dengan angka korelasi $r$ $=0,725($ Tabel 3).
\end{abstract}

\section{PEMBAHASAN}

Seperti yang telah dijelaskan bahwa karakteristik subyek penelitian seluruhnya adalah pasien yang melakukan pemeriksaan kadar asam urat dan kristal asam urat pada urine, maka ditemukan bahwa ada hubungan antara kadar asam urat dalam darah dan ditemukannya kristal asam urat dalam urine. Secara teori, hiperurisemia terjadi akibat peningkatan produksi asam urat atau penurunan ekskresi asam urat urine atau sering merupakan kombinasi keduanya.

Hiperurisemia akibat peningkatan produksi hanya sebagian kecil dari pasien dengan hiperurisemia itu pun biasanya disebabkan oleh diet tinggi purin (eksogen) ataupun proses endogen (pemecahan asam nukleat yang berlebihan (8). Sedangkan ditemukannya asam urat dalam urine disebakan karena berbagai factor seperti ekskresi asam urat melalui ginjal tergantung pada kandungan purin dalam makanan. Diet rendah purin dapat menurunkan kadar asam urat hingga 0,8 mg/100 ml, sebaliknya konsumsi tinggi purin akan mengakibatkan ekskresi urat urin tinggi sampai 1000 mg/hari (9).

Hiperurisemia adalah keadaan dimana terjadi peningkatan kadar asam urat darah diatas normal. Secara biokimia akan terjadi hipersaturasi yaitu kelarutan asam urat pada serum yang melewati ambang batasnya. Keadaan hiperurisemia akan berisiko timbulnya arthritis gout, nefro patigout atau batu ginjal. Asam urat terbentuk jika kita mengkonsumsi makanan yang banyak mengandung purin. Jika pola makan kita tidak di ubah maka kadar asam urat dalam darah yang berlebihan akan menimbulkan penumpukan kristal asam urat (4). Bila kristal urat tertimbun pada jaringan di luar sendi maka akan membentuk tofi atau topus yaitu benjolan bening di bawah kulit yang berisi kristal urat. Kristal urat ini juga dapat menyebabkan timbulnya batu asam urat (batu ginjal) (5). 
Pengontrolan asam urat secara

rutin dan upaya-upaya pengaturan pola hidup dapat membantu dalam pencegahan arthritis gout, nefropatigout atau batu ginjal. Terapi farmakologis berupa pemberian obat allopurinol yang akan membantu menurunkan kadar asam urat dalam darah. Allopurinol merupakan obat yang dapat menghambat tahap akhir dari biosintesis asam urat. Terapi farmakologislain yang pada umumnya diberikan pada pasien asam urat adalah kumarin, probenesid dan lainlain. Walaupun demikian, pengaturan pola hidup yang baik melalui terapi non farmakologis tetap disarankan bagi pasien yang terkena asam urat (10).

\section{KESIMPULAN}

Kadar asam urat dalam darah mempunyai hubungan yang kuat dengan kristal asam urat dalam urine dimana semakin besar ekskresi asam urat dalam urine maka akan menurunkan kadar asam urat dalam darah.

\section{DAFTAR PUSTAKA}

Departemen Kesehatan Republik Indonesia, Kebijakan dan Strategi Nasional Pencegahan dan Penanggulangan Penyakit
Tidak Menular, Jakarta, Depkes, 2003.

Misnadiarly, Asam Urat Hiperurisemia - Arthritis Gout, Jakarta, Pustaka Obor Populer, 2007.

Price AS \& Wilson LM. Patofisiologi Konsep Klinis Proses-proses Penyakit. Ed. 6. EGC. Jakarta. 2006.

Vitahealth, Asam Urat, Jakarta, Gramedia Pustaka Utama, 2007.

Yatim F, Penyakit Tulang dan Persendian, Jakarta, Pustaka Obor Populer, Edisi 1, 2006.

Mansjoer A, Suprohaita, Wardhan W.I dan Setiowulan W. Kapita Selekta Kedokteran. Ed. 3 jil. 1. Media Esculapius FK UI. Jakarta. 2009.

Evelyn C.P. Cara Mudah Mencegah, Mengobati Asam Urat dan Hipertensi. PT. Gramedia. Jakarta. 2008.

Signh V, Gomez VV, Swamy SG, 'Approachto a Case of Hyperuricemia', in Indian JAerospace Med, 2010, vol 54.

Rothman KJ, Epidemiologi in Introduction, New York, Oxford university press,2002.

Hastono S.P, Sabri L. Statistik Kesehatan. Rajawali Pers. Jakarta. 2010.Arozal, Wawaimuli \& Sulistia Gen. Antipurin Farmakologi dan Terapi. Ed. 5. Balai Penerbit FKUI. Jakarta. 2009. 